\title{
Birth weight and gestational age: Early life management strategy to population health for glucose disorders
}

\author{
Issa Al Salmi ${ }^{1 *}$ and Suad Hannawi \\ 1The Renal Medicine Department, the Royal Hospital, Muscat, Oman \\ 2The Rheumatology Medicine Department, MOHAP, Dubai, UAE
}

\begin{abstract}
Non-Communicable Disease (NCD) including dysglycemia is becoming an epidemic public health issues in many countries around the world. Similarly. Low Birth Weight (LBW) is increasing world-wide as more and more babies being kept alive with advancement of health care. This issues of NCD and LBW is by far more common in developing countries and worse situations occur in certain Asians countries where LBW reaches almost 20 per 100 population live birth.

LBW is associated with a higher risk for the development of diabetes and other metabolic disorders. Those being born Small for Gestational Age (SGA) and of LBW is associated with Type 2 Diabetes Mellitus (T2DM) in a non-genetic manner, and programming of muscle insulin action and signaling represents an early mechanism responsible for this association. Also, insulin secretory abnormalities in LBW may result from appropriate fetal adaptation ("programming") to a suboptimal nutritional state during intrauterine life but ultimately are maladaptive when presented with a high-carbohydrate diet after weaning. With the superimposition of age-related or dietary insulin resistance, insulin secretory responses are inadequate, resulting in progressive glucose intolerance.

The care of maternal health and prenatal care is of paramount importance to improve the birth weight and reduce the rate of LBW and prematurity. Postnatal care is similarly of great importance to further reduce the impact of LBW on non-communicable disease with the burden of obesity and increasing the metabolic demand upon the pancreatic cells.
\end{abstract}

\section{Introduction}

Metabolic syndrome is a constellation of metabolic abnormalities including centrally distributed obesity, decreased high-density lipoprotein cholesterol, elevated triglycerides, elevated blood pressure, and hyperglycaemia. It is associated with the development of diabetes and cardiovascular disease.

Currently, more than $75 \%$ of the disease burden in Oman is attributable to non-communicable diseases, with cardiovascular disease as the leading cause of death [1]. The distribution of chronic diseases and related risk factors among the general population is like that of industrialized nations; $12 \%$ of the population has diabetes, $30 \%$ are overweight, $20 \%$ are obese, $41 \%$ has high cholesterol, and $21 \%$ has metabolic syndrome [1].

Low Birth Weight (LBW) is increasing world-wide as more and more babies being kept alive with advancement of health care. Many of these babies nowadays are born less than 1 kilogram in weight and even less than 750 gram in weight. Although in many developed countries the average birth weight is between 3.5 and $4.0 \mathrm{~kg}$, most developing countries average birth weight is less than $3 \mathrm{~kg}$.

LBW may be due to Intra-Uterine Growth Retardation (IUGR), prematurity, or both; epidemiological studies do not always separate the two conditions [2]. LBW is a key indicator of health status throughout the world (ref). Prematurity is defined as a gestational age of less than 37 weeks. LBW is defined as a birthweight less than 2,500 grams. Babies weighing less than 1,500 grams are categorized as very low birth weight and those less than 1,000 grams as extreme low birth weight. IUGR is defined as a birthweight below the 10th percentile for gestational age [2].
LBW is a surrogate marker of an adverse fetal environment, is associated with development of insulin resistance and Type 2 Diabetes (T2DM), insulin resistance and obesity.

Thrifty hypothesis suggests that T2DM and other various components of metabolic syndrome result from inadequate intrauterine conditions for optimal fetal growth (ref). Several studies have demonstrated a higher risk of diabetes or impaired glucose tolerance in relation to LBW [3]. Despite number of critics, thrifty phenotype has downplayed an important role for genetic factors in the aetiology of T2DM and recently concluded that "environmental, probably nutritional factors operating in early life play a major causative role in T2DM. Barker et al. concluded that T2DM and hypertension have a common origin in sub-optimal development in utero, and that syndrome X should perhaps be re-named "the small-baby" [4]. It is suggested that the association between LBW and diabetes development in adulthood reflects the long-term effects of reduced growth of the endocrine pancreas and other tissues in utero, which may be a consequence of maternal undernutrition.

\section{Epidemiological evidence}

Studies in several countries have shown that children who were small at birth have an inability to respond to an oral glucose challenge

*Correspondence to: Issa Al Salmi, The Royal Hospital, P O Box 1331, code 111, Muscat, Oman, Tel: 968-927-090-00; Fax: 968-245-999-66; E-mail: isa@ ausdoctors.net

Received: September 28, 2018; Accepted: October 12, 2018; Published: October 17,2018 
[4-7]. Thinness at birth, as measured by a low ponderal index (birthweight/length), is associated with the occurrence of insulin resistance syndrome', which includes impaired glucose tolerance, raised blood pressure and disturbed lipid metabolism, in adult life [7-11]. Researchers in the mid-1980s found an inverse relationship between 'syndrome $\mathrm{x}$ ', which includes T2DM, hypertension, hyperlipidaemia, and birthweight, and renamed it as 'small baby syndrome' [8]. A review of 32 publications revealed a strong relationship between birthweight or thinness at birth, indicated by a low ponderal index and later development of T2DM, and metabolic syndrome [10].

\section{Muscle mass and metabolic syndrome}

Skeletal muscle is the most plentiful tissue in the body and the major pool of protein in the body. It transports glucose in an insulindependent physiological mechanism by the Glucose-Transportertype-4 (GLUT4) and contributes in the preservation of serum amino acids concentration. By its mass and energetic requirements, it is fundamental for the systemic metabolic balance (ref). Babies who are thin at birth lack muscle as well as fat, and muscle in adult life is the major site of insulin action [12,13]. It is thought that at some point in middle to late gestation, the thin neonate became undernourished, and in response its muscles became resistant to insulin and, hence, later development of T2DM [9,10,14-16]. Animal studies show that, in an adaptation to the poor nutrition, the expression of hormone receptors does change, where insulin and catecholamines receptors increased but expression of glucagon receptors decreased [17-19]. Skeletal muscle responsible for the most of insulin-stimulated glucose clearance, and flaws in muscle insulin action denote an initial indicator for diabetes risk [20-22]. Healthy population with LBW has reduced muscle mass and hence implying a role for skeletal muscle in the pathogenesis of insulin resistance in LBW.

Also, LBW people display a disproportionately amplified, incomplete fatty acid oxidation and a decreased glucose oxidation, compared with normal birth weight individuals, and hence have an increased risk of developing insulin resistance and T2DM [23-25]. Therefore, the higher amino acid levels in LBW individuals could be a consequence of their reduction in skeletal muscle insulin sensitivity due to overfeeding with a possible increased skeletal muscle proteolysis and/or could potentially contribute to an impaired insulin sensitivity [26-30]. It has been shown that LBW individuals have a higher fasting blood glucose level after the control diet compared with normal birth weight individuals and the increased gluconeogenesis, occurring parallel to an increased hepatic fatty acid oxidation, may contribute to this $[29,31]$.

\section{Pancreatic secretions}

Many metabolic studies have demonstrated both glucose intolerance and hyperinsulinemia in LBW individuals [32]. While insulin sensitivity is reduced in few studies of both children and adults, additional studies have emphasized the role of $\beta$-cell dysfunction as a key contributor to LBW-associated T2DM [32-34]. Collectively, these data demonstrate the seemingly heterogeneity of LBWassociated diabetes and recommend that both insulin resistance and secretory abnormalities contribute to the final phenotype in humans. Hyperinsulinemia in population of LBW reflects insulin resistance, even with using the less precise homeostasis model assessment or intravenous glucose tolerance modelling approaches [35-38]. Potential contributors to the variability in insulin sensitivity in LBW are likely to include the population under study, methods used for metabolic assessment, the underlying cause of aberrant fetal growth, postnatal catch-up growth, and other postnatal risk factors, including aging, obesity, and inactivity [38-41].

There are two main principal possibilities when considering the origin of hyperinsulinemia and subsequent glucose intolerance and T2DM [39, 42]. firstly, abnormal insulin clearance despite normal insulin sensitivity and develop progressive glucose intolerance [4244]. Secondly, abnormalities in $\beta$-cell function could also contribute to the early hyperinsulinemia and glucose intolerance $[16,30,32,45]$. Abnormal $\beta$-cell function or mass has been linked to LBW-related metabolic disorders with possibility of either altered $\beta$-cell mass or a functional $\beta$-cell defect resulting in abnormal glucose-stimulated insulin release $[16,32,33,45]$. Whether $\beta$-cell mass reduction is due to lower insulin gene transcription, biosynthesis, and/or accumulation is still not yet fully understood, but differences in insulin content clearly cannot account for hyperinsulinemia. Instead it points to intrinsic dysregulation of glucose-stimulated insulin secretion [46].

Researchers found that the secretory defect in undernutrition pancreatic islets is initially characterized by inability to modulate insulin secretion relative to ambient glucose, with a secondary decline in glucose-stimulated insulin secretion with aging [32,47]. With age advancement there are more inability to increase insulin secretion to compensate for age-related insulin resistance and thus develop progressive glucose intolerance $[36,40,42,48]$.

LBW people may have glucokinase mutations and this reduced glucokinase expression during fetal life reduces fetal insulin secretion and, therefore, reduces fetal growth [49-51]. Hence, the fetal insulin hypothesis states that, maternal undernutrition results in a low fetal glucose and nutrient milieu, which "programs" (low) fetal glucokinase activity and (high) hexokinase activity to ensure appropriate insulin secretion [32,52,53]. Of course, alterations in expression/function of other key genes that regulate insulin synthesis/secretion and the in vivo environment of undernutrition pancreatic islets may also modulate insulin secretion [32,52-55]. It is likely that the precise mechanisms that contribute to spontaneous LBW are critical in determining the final $\beta$-cell phenotype.

\section{The inverse relationship between birthweight and glu- cose disorders}

Al Salmi et al. found that in an affluent Western country with a good adult health profile, birth weight has an inverse relationship with indexes of glycemia, and individuals with LBW were predisposed to higher rates of glycemic dysregulation in adult life [56]. In their study, 4,502 participants with birth weights mean \pm SD of $3.4 \pm 0.7$ $\mathrm{kg}$. They found that FPG, PLG, and A1C were strongly and inversely correlated with birth weight. The odds ratios (95\% CI) for high (> 90th sex-specific percentile) FPG, PLG, and A1C were 0.83 (0.71-0.96), 0.74 (0.65-0.84), and $0.81(0.70-0.94)$, respectively, for a 1-kg increase in birth weight after adjustment for age and sex. In those with Low Birth Weight (LBW), the risks for having IFG, IGT, and diabetes and for all abnormalities combined were increased by $1.75,2.22,2.76$, and 2.28 , respectively, for women and by $1.40,1.32,1.98$, and 1.49 for men compared with risks for those with normal birth weight. These trends applied across categories of age and BMI.These associations were independent of Body Mass Index (BMI) and of other factors significantly correlated with glycemic dysregulation [56].

Many researchers have reported the association between LBW and the increased risk of, and the earlier onset of type 1 diabetes during adulthood, giving rise to the "thrifty hypothesis". This hypothesis as 
stated earlier proposes that inadequate nutrition programmes the foetus to develop resistance to an insulin-stimulated uptake of glucose in late life [57-62]. This inverse relationship between LBW and, impaired glucose tolerance and elevated serum insulin, occurs across a whole range of ages and in both sexes and racial backgrounds [3,10,37,61-64]. It may be determined by a genetic defect in insulin action that manifests itself in utero as reduced growth, and in later life as an impairment of an insulin-stimulated uptake of glucose. In this scenario it is proposed that the poorly nourished mother essentially gives the foetus a forecast of the nutritional environment into which it will be born. Processes are set in motion, leading to a postnatal metabolism adapted to survival under conditions of poor nutrition. The adaptations only become detrimental when the postnatal environment differs from the mother's forecast, with an overabundance of nutrients and consequent obesity [10].

A U-shaped curve relationship exists between birthweight and, glucose as seen in the Pima Indians and the Nurses' Health Study (NHS) $[63,64]$. As such, both LBW individuals and heavy birthweight individuals are at higher risk of developing as adult. The heavy birthweight phenomenon has been attributed to gestational diabetes, which by its self is associated with increased risk of in adult off spring [63].

\section{Hertfordshire study}

In a study of men in Hertfordshire in 1991, glucose tolerance tests were performed on 64-year-old men for whom birthweight records were available. The proportion of men with impaired glucose tolerance (2-hours (h) plasma glucose 7.8-11.0 millimoles/litre $(\mathrm{mM} / \mathrm{L})$ ) or (2-hplasma glucose $>11.0 \mathrm{mM} / \mathrm{L}$ ) steadily increased with decreasing birthweight. This relationship was continuous across the birthweight categories, with those men who were smallest at birth $(<2.5 \mathrm{~kg})$ being nearly seven times more likely to have impaired glucose tolerance than those who were heaviest at birth (>4.3 kg) [65].

In the same Hertfordshire cohort, researchers found an inverse relationship between birthweight and the current presence of metabolic syndrome [4]. Metabolic syndrome was defined as glucose intolerance ( 2 -h glucose $>7.8 \mathrm{mM} / \mathrm{L}$ ), systolic blood pressure $>160 \mathrm{mmHg}$, and a fasting plasma triglyceride concentration equal to or above the median concentration for that population $(\geq 1.4 \mathrm{mM} / \mathrm{L})$. Metabolic syndrome increased with decreasing birthweight, so that men with the smallest weight at birth were 18 times more likely to have the metabolic syndrome than those who were heaviest at birth. The prevalence of metabolic syndrome fell from $30 \%$ to $6 \%$ between those who were small, and those who were heavy at birth [4].

\section{The effect of obesity during childhood}

Obesity in childhood has a greater effect on the development of metabolic syndrome than does obesity in adulthood [66]. However, the Helsinki cohort, born 1924-1933, showed that the development of insulin resistance was associated with thinness at birth, and continued thinness in childhood, followed by the development of obesity in adult life [35,67]. The foetal growth restriction leads to a reduced cell number in the endocrine pancreas and subsequent accelerated growth in childhood leads to excessive metabolic demands on the limited cell mass. Men and women, in a Dutch study, exposed to a brief period of intense starvation in utero but who were well nourished as children, had higher plasma glucose concentrations, higher pro-insulin and insulin concentration, and therefore exhibited insulin resistance [41].

\section{Conclusion}

LBW is a significant risk factor for T2DM, understanding the pathophysiology of LBW-associated glucose intolerance is important for both prevention and therapy. The care of maternal health and prenatal care is of paramount importance to improve the birth weight and reduce the rate of LBW and prematurity. Postnatal care is similarly of great importance to further reduce the impact of LBW on noncommunicable disease with the burden of obesity and increasing the metabolic demand upon the pancreatic cells. Early detection of various metabolic risk factors in this specific group of population is an important strategy from public health perspective to allow early intervention and management.

\section{References}

1. Al-Lawati JA, Mabry R, Mohammed AJ (2008) Addressing the threat of chronic diseases in Oman. Prev Chronic Dis 5: A99. [Crossref]

2. Battaglia FC, Lubchenco LO (1967) A practical classification of newborn infants by weight and gestational age. J Pediatr 71: 159-163. [Crossref]

3. Curhan GC, Willett WC, Rimm EB, Spiegelman D, Ascherio AL, et al. (1996) Birth weight and adult hypertension, diabetes mellitus, and obesity in US men. Circulation 94: 3246-3250. [Crossref]

4. Barker DJ, Hales CN, Fall CH, Osmond C, Phipps K, et al. (1993) Type 2 (non-insulindependent) diabetes mellitus, hypertension and hyperlipidaemia (syndrome $\mathrm{X}$ ): relation to reduced fetal growth. Diabetologia 36: 62-67. [Crossref]

5. Yajnik CS, Fall CH, Vaidya U, Pandit AN, Bavdekar A, et al. (1995) Fetal growth and glucose and insulin metabolism in four-year-old Indian children. Diabet Med 12: 330-336. [Crossref]

6. Law CM (1996) Fetal and infant influences on non-insulin-dependent diabetes mellitus (NIDDM). Diabet Med 13: S49-52. [Crossref]

7. Law CM, Gordon GS, Shiell AW, Barker DJ, Hales CN (1995) Thinness at birth and glucose tolerance in seven-year-old children. Diabet Med 12: 24-29. [Crossref]

8. Phillips DI, Barker DJ, Hales CN, Hirst S, Osmond C (1994) Thinness at birth and insulin resistance in adult life. Diabetologia 37: 150-154. [Crossref]

9. McKeigue PM, Lithell HO, Leon DA (1998) Glucose tolerance and resistance to insulin-stimulated glucose uptake in men aged 70 years in relation to size at birth Diabetologia 41: 1133-1138. [Crossref]

10. Hales CN, Barker DJ (2001) The thrifty phenotype hypothesis. Br Med Bull 60: 5-20. [Crossref]

11. Hales CN (1997) Fetal and infant origins of adult disease. J Clin Pathol 50: 359 [Crossref]

12. Beauchamp B, Ghosh S, Dysart MW, Kanaan GN, Chu A, et al. (2015) Low birth weight is associated with adiposity, impaired skeletal muscle energetics and weight loss resistance in mice. Int J Obes (Lond) 39: 702-711. [Crossref]

13. Vaag A, Jensen CB, Poulsen P, Brons C, Pilgaard K, et al. (2006) Metabolic aspects of insulin resistance in individuals born small for gestational age. Horm Res $65 \mathrm{Suppl}$ 3: 137-143. [Crossref]

14. Fowden AL (1993) Insulin deficiency: effects on fetal growth and development. $J$ Paediatr Child Health 29: 6-11. [Crossref]

15. Fowden AL, Hill DJ (2001) Intra-uterine programming of the endocrine pancreas. $\mathrm{Br}$ Med Bull 60: 123-142. [Crossref]

16. Hansen NS, Hjort L, Broholm C, Gillberg L, Schrolkamp M, et al. (2016) Metabolic and Transcriptional Changes in Cultured Muscle Stem Cells from Low Birth Weight Subjects. J Clin Endocrinol Metab 101: 2254-2264. [Crossref]

17. Ozanne SE, Wang CL, Coleman N, Smith GD (1996) Altered muscle insulin sensitivity in the male offspring of protein-malnourished rats. Am J Physiol 271(6 Pt 1): E11281134. [Crossref]

18. Petry CJ, Dorling MW, Wang CL, Pawlak DB, Ozanne SE (2000) Catecholamine levels and receptor expression in low protein rat offspring. Diabet Med 17: 848-853. [Crossref]

19. Petry CJ, Ozanne SE, Wang CL, Hales CN (2000) Effects of early protein restriction and adult obesity on rat pancreatic hormone content and glucose tolerance. Horm Metab Res 32: 233-239. [Crossref]

20. DeFronzo RA, Tripathy D (2009) Skeletal muscle insulin resistance is the primary defect in type 2 diabetes. Diabetes Care 32 Suppl 2: S157-163. [Crossref] 
21. Pratipanawatr W, Pratipanawatr T, Cusi K, Berria R, Adams JM, et al. (2001) Skeletal muscle insulin resistance in normoglycemic subjects with a strong family history of type 2 diabetes is associated with decreased insulin-stimulated insulin receptor substrate-1 tyrosine phosphorylation. Diabetes 50: 2572-2578. [Crossref]

22. Sriwijitkamol A, Christ-Roberts C, Berria R, Eagan P, Pratipanawatr T, et al. (2006) Reduced skeletal muscle inhibitor of kappaB beta content is associated with insulin resistance in subjects with type 2 diabetes: reversal by exercise training. Diabetes 55 : 760-767. [Crossref]

23. Ribel-Madsen A, Ribel-Madsen R, Nielsen KF, Brix S, Vaag AA, et al. (2018) Plasma ceramide levels are altered in low and normal birth weight men in response to shortterm high-fat overfeeding. Sci Rep 8: 3452. [Crossref]

24. Schultz NS, Broholm C, Gillberg L, Mortensen B, Jorgensen SW, et al. (2014) Impaired leptin gene expression and release in cultured preadipocytes isolated from individuals born with low birth weight. Diabetes 63: 111-121. [Crossref]

25. Vienberg SG, Brons C, Nilsson E, Astrup A, Vaag A, et al. (2012) Impact of short-term high-fat feeding and insulin-stimulated FGF21 levels in subjects with low birth weight and controls. Eur J Endocrinol 167: 49-57. [Crossref]

26. Barker DJ, Thornburg KL, Osmond C, Kajantie E, Eriksson JG (2010) The prenatal origins of lung cancer. II. The placenta. Am J Hum Biol 22: 512-516. [Crossref]

27. Getty CM, Almeida FN, Baratta AA, Dilger RN (2015) Plasma metabolomics indicates metabolic perturbations in low birth weight piglets supplemented with arginine. J Anim Sci 93: 5754-63. [Crossref]

28. Master JS, Thouas GA, Harvey AJ, Sheedy JR, Hannan NJ, et al. (2015) Low female birth weight and advanced maternal age programme alterations in next-generation blastocyst development. Reproduction 149: 497-510. [Crossref]

29. Ribel-Madsen A, Hellgren LI, Brons C, Ribel-Madsen R, Newgard CB, et al. (2016) Plasma amino acid levels are elevated in young, healthy low birth weight men exposed to short-term high-fat overfeeding. Physiol Rep 4. E13044. [Crossref]

30. Velazquez MA, Sheth B, Smith SJ, Eckert JJ, Osmond C, et al. (2018) Insulin and branched-chain amino acid depletion during mouse preimplantation embryo culture programmes body weight gain and raised blood pressure during early postnatal life. Biochim Biophys Acta Mol Basis Dis 1864: 590-600. [Crossref]

31. Brons C, Lilleore SK, Jensen CB, Toubro S, Vaag A, et al. (2013) Increased nocturnal fat oxidation in young healthy men with low birth weight: results from 24-h wholebody respiratory chamber measurements. Metabolism 62: 709-716. [Crossref]

32. Jimenez-Chillaron JC, Hernandez-Valencia M, Reamer C, Fisher S, Joszi A, et al (2005) Beta-cell secretory dysfunction in the pathogenesis of low birth weightassociated diabetes: a murine model. Diabetes 54: 702-711. [Crossref]

33. Barg E, Szopa J, Pesz KA, Gasiorowski K (2013) Indices of insulin resistance and dyslipidemia are correlated with lymphocyte proneness to apoptosis in obese or overweight low birth weight children. Horm Res Paediatr 79: 293-299. [Crossref]

34. Fall CH, Stein CE, Kumaran K, Cox V, Osmond C, et al. (1998) Size at birth, maternal weight, and type 2 diabetes in South India. Diabet Med 15: 220-227. [Crossref]

35. Eriksson JG, Forsen T, Tuomilehto J, Jaddoe VW, Osmond C, et al. (2002) Effects of size at birth and childhood growth on the insulin resistance syndrome in elderly individuals. Diabetologia 45: 342-348. [Crossref]

36. Fall CH, Sachdev HS, Osmond C, Lakshmy R, Biswas SD, et al. (2008) Adult metabolic syndrome and impaired glucose tolerance are associated with different patterns of BMI gain during infancy: Data from the New Delhi Birth Cohort. Diabetes Care 31: 23492356. [Crossref]

37. Li C, Johnson MS, Goran MI (2001) Effects of low birth weight on insulin resistance syndrome in caucasian and African-American children. Diabetes Care 24: 2035-42. [Crossref]

38. Raghupathy P, Antonisamy B, Geethanjali FS, Saperia J, Leary SD, et al. (2010) Glucose tolerance, insulin resistance and insulin secretion in young south Indian adults: Relationships to parental size, neonatal size and childhood body mass index. Diabetes Res Clin Pract 87: 283-292. [Crossref]

39. Bhargava SK, Sachdev HS, Fall CH, Osmond C, Lakshmy R, et al. (2004) Relation of serial changes in childhood body-mass index to impaired glucose tolerance in young adulthood. $N$ Engl J Med 350: 865-875. [Crossref]

40. Eriksson JG, Osmond C, Kajantie E, Forsén TJ, Barker DJ (2006) Patterns of growth among children who later develop type 2 diabetes or its risk factors. Diabetologia 49 : 2853-2858. [Crossref]

41. Ravelli AC, van der Meulen JH, Michels RP, Osmond C, Barker DJ, et al. (1998) Glucose tolerance in adults after prenatal exposure to famine. Lancet 351: 173-177. [Crossref]
42. Barker DJ (2005) The developmental origins of insulin resistance. Horm Res 64 Suppl 3: 2-7. [Crossref]

43. Mi J, Law C, Zhang KL, Osmond C, Stein C, et al. (2000) Effects of infant birthweight and maternal body mass index in pregnancy on components of the insulin resistance syndrome in China. Ann Intern Med 132: 253-260. [Crossref]

44. Sayers SM, Mott SA, Mann KD, Pearce MS, Singh GR (2013) Birthweight and fasting glucose and insulin levels: results from the Aboriginal Birth Cohort Study. Med J Aust 199: 112-116. [Crossref]

45. Ponzio C, Palomino Z, Puccini RF, Strufaldi MW, Franco MC (2013) Does low birth weight affect the presence of cardiometabolic risk factors in overweight and obese children? Eur J Pediatr 172: 1687-1692. [Crossref]

46. Gillberg L, Perfilyev A, Brons C, Thomasen M, Grunnet LG, et al. (2016) Adipose tissue transcriptomics and epigenomics in low birthweight men and controls: role of high-fat overfeeding. Diabetologia 59: 799-812.

47. Cerf ME, Williams K, Nkomo XI, Muller CJ, Du Toit DF, et al. (2005) Islet cell response in the neonatal rat after exposure to a high-fat diet during pregnancy. Am $J$ Physiol Regul Integr Comp Physiol 288: R1122-1128. [Crossref]

48. Thomas N, Grunnet LG, Poulsen P, Christopher S, Spurgeon R, et al. (2012) Born with low birth weight in rural Southern India: what are the metabolic consequences 20 years later? Eur J Endocrinol 166: 647-655. [Crossref]

49. Hattersley AT, Beards F, Ballantyne E, Appleton M, Harvey R, et al. (1998) Mutations in the glucokinase gene of the fetus result in reduced birth weight. Nat Genet 19: 268 270. [Crossref]

50. Shields BM, Spyer G, Slingerland AS, Knight BA, Ellard S, et al. (2008) Mutations in the glucokinase gene of the fetus result in reduced placental weight. Diabetes Care 31: 753-757.

51. Terauchi Y, Kubota N, Tamemoto H, Sakura H, Nagai R, et al. (2000) Insulin effect during embryogenesis determines fetal growth: a possible molecular link between birth weight and susceptibility to type 2 diabetes. Diabetes 49: 82-86. [Crossref]

52. Mortensen B, Hingst JR, Frederiksen N, Hansen RW, Christiansen CS, et al. (2013) Effect of birth weight and 12 weeks of exercise training on exercise-induced AMPK signaling in human skeletal muscle. Am J Physiol Endocrinol Metab 304: E1379-1390. [Crossref]

53. Sheppard A, Ngo S, Li X, Boyne M, Thompson D, et al. (2017) Molecular Evidence for Differential Long-term Outcomes of Early Life Severe Acute Malnutrition. EBioMedicine 18: 274-80. [Crossref]

54. Balamurugan R, Vendan SE, Aravinthan A, Kim JH (2015) Isolation and structural characterization of $2 \mathrm{R}, 3 \mathrm{R}$ taxifolin 3-O-rhamnoside from ethyl acetate extract of Hydnocarpus alpina and its hypoglycemic effect by attenuating hepatic key enzymes of glucose metabolism in streptozotocin-induced diabetic rats. Biochimie 111: 70-81. [Crossref]

55. Heywood WE, Mian N, Milla PJ, Lindley KJ (2004) Programming of defective ra pancreatic beta-cell function in offspring from mothers fed a low-protein diet during gestation and the suckling periods. Clin Sci (Lond) 107: 37-45. [Crossref]

56. Al Salmi I, Hoy WE, Kondalsamy-Chennakesavan S, Wang Z, Gobe GC, et al. (2008) Disorders of glucose regulation in adults and birth weight: results from the Australian Diabetes, Obesity and Lifestyle (AUSDIAB) Study. Diabetes Care 31: 159-164. [Crossref]

57. Fowden AL (1989) The role of insulin in prenatal growth. J Dev Physiol 12: 173-182. [Crossref]

58. Fowden AL, Forhead AJ (2004) Endocrine mechanisms of intrauterine programming Reproduction 127: 515-526. [Crossref]

59. McCance DR, Pettitt DJ, Hanson RL, Jacobsson LT, Bennett PH, et al. (1994) Glucose, insulin concentrations and obesity in childhood and adolescence as predictors of NIDDM. Diabetologia 37: 617-623. [Crossref]

60. Khan N, Couper JJ (1994) Low-birth-weight infants show earlier onset of IDDM Diabetes Care 17: 653-656. [Crossref]

61. Hales CN, Barker DJ (1992) Type 2 (non-insulin-dependent) diabetes mellitus: the thrifty phenotype hypothesis. Diabetologia 35: 595-601. [Crossref]

62. Robinson S, Walton RJ, Clark PM, Barker DJ, Hales CN, et al. (1992) The relation of fetal growth to plasma glucose in young men. Diabetologia 35: 444-446. [Crossref]

63. Rich-Edwards JW, Colditz GA, Stampfer MJ, Willett WC, Gillman MW, et al. (1999) Birthweight and the risk for type 2 diabetes mellitus in adult women. Ann Intern Med 130: 278-284. [Crossref] 
64. Dabelea D, Pettitt DJ, Hanson RL, Imperatore G, Bennett PH, et al. (1999) Birth weight, type 2 diabetes, and insulin resistance in Pima Indian children and young adults. Diabetes Care 22: 944-950. [Crossref]

65. Hales CN, Barker DJ, Clark PM, Cox LJ, Fall C, et al. (1991) Fetal and infant growth and impaired glucose tolerance at age 64. BMJ 303: 1019-1022. [Crossref]
66. Vanhala M, Vanhala P, Kumpusalo E, Halonen P, Takala J (1998) Relation between obesity from childhood to adulthood and the metabolic syndrome: population-based study. BMJ 317: 319. [Crossref]

67. Forsen T, Eriksson J, Tuomilehto J, Reunanen A, Osmond C, et al. (2000) The fetal and childhood growth of persons who develop type 2 diabetes. Ann Intern Med 133: 176-182. [Crossref]

Copyright: (C2018 Salmi IA. This is an open-access article distributed under the terms of the Creative Commons Attribution License, which permits unrestricted use, distribution, and reproduction in any medium, provided the original author and source are credited. 